\author{
N.K. Baigazieva ${ }^{1}$, D.T. Teshebaeva ${ }^{1}$ \\ ${ }^{1}$ Kyrgyz State Medical Academy named after I.K. Akhunbaev, Bishkek, Kyrgyz Republic
}

\author{
Н.К. Байгазиева ${ }^{1}$, Д.Т Тешебаева ${ }^{1}$ \\ ${ }^{1}$ Кыргызская Государственная Медицинская Академия имени И.К. Ахунбаева, \\ Бишкек, Кыргызская Республика \\ dinarateshebaeva@gmail.com
}

\title{
STYLISTIC PECULIARITIES OF THE TRANSLATION OF SOMATIC PHRASEOLOGICAL UNITS
}

\section{СОМАТИКАЛЫК ФРАЗЕОЛОГИЗМДЕРДИ КОТОРУУНУН СТИЛИСТИКАЛЫК ӨЗГӨЧӨЛУКТӨРУ}

\section{СТИЛИСТИЧЕСКИЕ ОСОБЕННОСТИ ПЕРЕВОДА СОМАТИЧЕСКИХ ФРАЗЕОЛОГИЗМОВ}

Бул макалада соматикальк фразеологизимдерди которуунун стилистикальк өзгөчөлүктөрүн кыргыз жана англис тилдеринде ачьлк көрсөтүҮ маселеси жана ошондой эле функииялары, алардын эмочиялык боектору, семантикалык жана тематикальк топтору каралган. Соматикальк топтордун окшоштуктарына жана айырмачылыктарына таянып тилдер ортосундагы өз ара байланышты жана адамдын турмушундагы ар түрдҮY аспектилерин чагылдыруучу соматизмдин экинчи маанилеринин пайда болуу процессин аныктоого болот. Кадыресе соматикалык сөз айкаштарынын окшоштуктарын жана айырмачылыктарын айырмаланып турган фразеологиялькк бирдиктерди кептин айрым бөлүктөрүнө кирген семантикалык жакындашуу баса белгилөөдө, алардын аспектик инструктивдик синонимдүүлүгүнө, жан түзүлүштүк өзгөчөлүктөрүнүн образдуулугуна, көнүл бурулган.

өзөк сөздөр: фразеологизм, соматика, идиома, метафора, стилистикалык ыкмалар, коннотация.

В данной статье рассматривается вопрос выяснения стилистических особенностей перевода соматических фразеологических единии на английском и кыргызском языках, $а$ также функции их эмоцииональных оттенков, семантическая нагрузка, их тематикосодержательные группы. Основываясь на соматических группах, сходствах и различиях, можно определить взаимосвязь между языками, исследовать прочесс формирования вторичных значений соматизмов, которые могут отражать различные аспекты человеческой жизни. Желая подчеркнуть, что выявление существенных лингвистических сходств и различий может осуществляться при различных условиях обобщения материала, в частности, при сравнении категорий фразеологии и цельх фразеологических систем, наряду с общими особенностями сравнительного анализа, внутриязыковыми описаниями, их сопоставимостью, выявлением межъязыковых различий на основе идентичностей, двусторонним направлением. Их внутренняя организащия (аспект инструктивносемантической корреляции) такова в их совместном содержании и функционировании (функционально-семантическая корреляция).

Ключевые слова: фразеологизм, соматика, идиома, метафора, стилистические приемы, коннотация. 
This article covers the issue of clarifying the stylistic peculiarities of the translation of somatic phraseological units in English and Kyrgyz languages, as well as their functions, emotional shades, semantic and thematic content groups. Based on somatic groups, similarities and differences, it is possible to determine the relationship between languages, to investigate the process of formation of secondary meanings of somatisms that may reflect various aspects of human life.

Wishing to emphasize that the identification of significant linguistic similarities and differences can be carried out under various conditions of generalization of the material, in particular, comparing the categories of phraseology and entire phraseological systems, along with the general features of comparative analysis, intra-linguistic descriptions, their comparability, identification of interlanguage differences based on identities, two-way direction. Their internal organization (aspect instructive-semantic correlation) so it is in their combined content and functioning (functional and semantic correlation).

Key words: phraseology, somatic, idiom, metaphor, stylistic techniques, connotation.

The current translation practice deals with original texts of various styles. It is difficult to reflect the author's state, feelings, and emotions in translation. Having a rich vocabulary is not enough, although this plays a minor role. It is necessary to be able to determine a clear reflection in the transmitted text. Sometimes it is necessary to use some techniques to give more expressiveness, sensuality to the created text. The approach to work through metaphors, metonymies, comparisons, allusions is very important.

The problem of language transmission by stylistic methods is an important aspect of translation theory. The need for an adequate transfer of figurative information of artwork is a key aspect for studying the translation of figurative means, recreating the stylistic effect in the translation of the original.

In order to decide which synonyms can be used in a particular text, it is necessary to turn to stylistic techniques, to bring the stylistic features of the original to give the text more brightness and expressiveness. Thus, there is a great opportunity to choose stylistic and rhetorical forms and tropes. It is the stylistic correspondence that will be the final criterion to help in selecting the required vocabulary, grammatical forms and sentence structures.

K. I. Chukovsky said that it is not necessary to convey a metaphor with a metaphor, a comparison with a comparison, but a smile with a smile, a tear with a tear, etc. But novice "masters of the word" need to remember that not only the form, but the function of a stylistic instrument in the text is much more important. This means a certain action: grammatical means of expression can be transferred to lexical ones and vice versa. Omitting a stylistic phenomenon that is not transferable into English language, the translator will return the "borrowed" text, by creating a different image in another place of the text-where it is most convenient, but with a similar stylistic orientation [1].

Translation of phraseological units often causes difficulties for translators due to the national peculiarities of stylistic systems of different languages. All linguists emphasize the need to preserve the image of the original in translation, rightly believing that, the translator should firstly strive to reproduce the function of techniques, and not technique itself. [2].

It is notable that in Kyrgyz translation studies there is a tendency towards Kyrgyz-English translation and at the same time, translations of a high degree of complexity are performed. One of the very talented translators in the field of English philology, Z.K. Karaeva, noted in her fundamental monograph "Translation is the interaction of two cultures, lifestyle, thinking and lifestyle in different regions of the world" [3]. When translating from the original language into the translated language, particularly from Kyrgyz to English and vice versa, different features of the relationship of language, the national flavor and cultural component should be taken into account.

Researchers distinguish two ways of translating phraseological units, namely phraseological (in the case of a phraseological unit there is a full or partial equivalent of the translation language) 
and non-phraseological (in the absence of a translation in a foreign language). Other methods of presenting information used in non-phrasological translation, such as tracing or descriptive translation are also applicable [4].

In the expression like "to kill two birds with one stone" - “бир ок менен эки коенду атуy" - the noun "bird" is replaced by "hare", despite the fact that they are not identical, readers of the translated text will fully understand the meaning, because in different languages such stylistic means as phraseological units differ, but carry the same meaning. [5].

The following phraseological unit has no equivalent in Kyrgyz or Russian languages, therefore descriptive translation is used: a skeleton in the cupboard - «уй булолук сыр, сырды жашыруy».

Lately, people have been showing increasing interest in phraseology, which includes nouns that have the original meaning of individual parts of the human body. It is worth mentioning the division of phraseological units by the source of origin and the spheres of human activity is the traditional way of classifying phraseological units. In modern phraseology, there are such phraseological units as classification according to the thematic principle. In this regard, phraseological units with the component "part of the human body" should be considered as a special class of vocabulary of the Kyrgyz language.

The names of body parts are the oldest and integral part of any language, they reflect the cultural and anthropological features of a particular nation. The somatic lexical stock appeared in the language one of the first, since people needed to designate their body parts, which was formed for a long time in the process of a person's cognition of his body, ideas about the world around him and about himself.

Somatisms are characterized by stability, high frequency of consumption and, as a result, an extensive semantic structure. The connection of somatisms with the real world, which are based on their principle of anthropomorphism, create conditions for the symbolization of the functions of various parts of body, for the formation of figurative meanings for the lexeme of this group and for the phraseologization of the use of somatic expressions. [6].

By somatisms, the linguistic means of denoting phenomena related to the sphere of somaticity are taken into account. The body and its structure are a common model for building a conceptual system of language, this is also true in the culture of many ethnic groups. Based on somatic groups, similarities and differences, people can determine the relationship between languages, explore the process of formation of secondary meanings of somatisms that can reflect various aspects of human life. The following Kyrgyz idioms are given as an example:

башы бар - mеans "smart", intelligent; балтыр эти толо элек - "still young", катуу баш -

"greedy", бели катуу - "strong, brave", чын жүрөктөн куттуктоо - "from the heart", in all sincerity, ак жүрөк - "a person of good intention", ак кол - "white hand"

Somatic phraseological units composed of lexemes and syntactic schemes make it necessary to take into account the peculiarities of the original lexical and grammatical schemes when comparing them. Therefore, the average and complex nature of the analysis, as well as its results, are close to the known ones. The peculiarity of comparing related and unrelated languages is the almost complete absence of material identity of comparative units. With the exception of relatively rare direct borrowings or parts of them from one language to another, or any third of its two comparable correlations can be found in English and Kyrgyz phraseological units both in lexical and syntactic aspects. [7].

When translating it is necessary to pay attention to their internal organization (aspect instruction-semantic correlation), their general content and functioning (functional - semantic correlation).

Aspect correlation means the interlanguage semantic proximity of phraseological components, as well as their syntactic structural constancy, non-phraseological use, that is, the same signs of the internal organization of the compared somatic phraseological units or at least their similarity. 


\section{Ex: face to face - бетме-бет}

Functional semantic correlation means the proximity of the schematic composition and additional connotations to the general content of the compared somatic phraseological units.

Practically, the functional-semantic correlation in somatic phraseological expressions of different languages is manifested in the fact that they act as regular correspondence in translation however, complete identity is achieved here only in interaction with aspect correlation.

to be at hand to - жанында, жакын болуу

to hold one's tongue - тилди тыйуy

to welcome someone/something with open arms - кучак жайып тосуп алуy

There are many somatic phraseological units in both languages, between which only a certain semantic, but not an aspect correlation is found:

to be up to the ears in something - баш оту мн киришуу, алек болуу

to open smb's eyes to smth. - тушунуу, козун ачуy

Thus, the interlanguage aspect and the functional-semantic correlation of somatic phraseological units are relatively autonomous phenomena, the typology of interlanguage phraseological equivalents is based on their interaction, among which the structural - semantic (combining aspect and functional - semantic correlation) is usually distinguished.

The complete or absolute phraseological equivalent is precisely the smaller part of the structural and semantic equivalents; for the rest, the equivalence fulfills what takes place in certain decorative - significative or connotative pragmatic differences.

In general, taking into account the aspectual and functional-semantic correlation between specific phraseological units of the English and Kyrgyz languages (more precisely, from individual values), the following qualitative types of interlanguage relations are found.

1. Identity, that is, an incomplete coincidence of the aspect organization and the totality of meaning. to bury one's head in the sand - кайгblza баmyy

2. Lexical variability or structural synonymy, that is, the complete correspondence of the general meaning and syntactic organization in the incomplete identity of the component composition.

to lead the nose - мурдунан жетелоо

Ideographic synonymy, that is, an incomplete identity of the features of a set of significative meaning (regardless of the aspect of identity) due to the presence of special phraseological units;

a stuff upper lip - кайраттуу,эр,турумдуy

3. Hypero-hyponemia, that is, incomplete identity of the features of a set of significative meaning (relative to the aspect identity) due to the presence of semantic additional features in some phraseological units.

to scream at the top of one's lungs - тамагы айрылганча кыйкыруу

Stylistic synonymy, that is, incomplete identical signs of a common meaning due to differences in stylistic coloring; (everyday colloquial)

to have one's hands full - жумуш чачтан коп

to be fed up to the back teeth - кекиртеке чейин ток

That is, the same signs of aspect organization with greater or lesser differences in general meanings:

the tongue stuck to the larynx of someone, someone fell silent from surprise, fear, etc.

\section{- тилди жутуу}

Consequently, important general comparative characteristics should be considered the information about the English - Kyrgyz and Kyrgyz - English somatic phraseological equivalents of various types in the phraseological composition of both languages.

The average indicators of the interlanguage equivalence of the English and Kyrgyz languages (both structural - semantic and functional-semantic) remain the same in all areas, have a somatic phraseological composition. On the contrary, there are various somatic phraseological units united by certain signs and showing significant deviations from the average values in one direction or another. 
Summing up the study of the given topic we have seen that the peculiar function of phraseological units is widely used to depict stylistic peculiarities, emotional color, and expressiveness. When translating somatic phraseological units, the most influential is the stylistic and linguistic method, which is more powerful, shows the creative personality and worldview of the translator. Accordingly, they give a volume of stylistic categories in any context to color the words and give the language sharpness.

\section{References}

1. Prozorov, V. G. Fundamentals of the theory and practice of translation from English into Russian / V. G. Prozorov, M., 1998.

2. Breeva, L. V., A. A. Butenko. Lexico-stylistic transformations in translation.

3. Karaeva Z.K. Translation and semiotics. Multilingual existence of the epic "Manas" and theoretical and methodological problems of translation studies. Bishkek: b.y.n., 2006. 332 p.

4. Fedorov A.V. Fundamentals of the general theory of translation: linguistic problems. Moscow: Higher School, 1983. 416 p.

5. Salimova D. A., Timerkhanov A. Bilingualism and translation: theory and research experience. Moscow: Liters, 2015. 280 p.

6. Karmyshakov A. O "Somatic phraseological units in the Russian and Kyrgyz languages" author's abstract. diss. candidate of Philology. - Bishkek, 1992.

7. KozerenkoA. D. Kreidlin G. E. Phraseological somaticisms and semiotic conceptualization of the body //Questions of linguistics 2011/6. 